\title{
The Effect of Catalase on Recovery of Heat-injured DNA-repair Mutants of Escherichia coli
}

\author{
By BERNARD M. MACKEY* AND DEBRA A. SEYMOUR \\ AFRC Institute of Food Research, Bristol Laboratory, Langford, Bristol BS18 7DY, UK
}

(Received 19 September 1986 ; revised 27 November 1986)

The apparent sensitivity of Escherichia coli $\mathrm{K} 12$ to mild heat was increased by $\operatorname{rec} A(\operatorname{def}), \operatorname{rec} B$
and pol $A$, but not by $u v r A, u v r B$ or $\operatorname{rec} F$ mutations. However, addition of catalase to the rich
plating medium used to assess viability restored counts of heat-injured $\operatorname{rec} A, \operatorname{rec} B$ and polA
strains to wild-type levels. E. coli p3478 polA was sensitized by heat to a concentration of
hydrogen peroxide similar to that measured in autoclaved recovery medium. The apparent heat
sensitivity of DNA-repair mutants is thus due to heat-induced sensitivity to the low levels of
peroxide present in rich recovery media. It is proposed that DNA damage in heated cells could
occur indirectly by an oxidative mechanism. The increased peroxide sensitivity of heat-injured
cells was not due to a decrease in total catalase activity but may be related specifically to
inactivation of the inducible catalase/peroxidase (HPI).

\section{INTRODUCTION}

Exposure of microbes to mild heat results in damage to many cell components including membranes, nucleic acids, ribosomes and proteins, but the critical events leading to loss of viability remain poorly understood (Hurst, 1984). Several workers have suggested that DNA may be an important target of heat injury (reviewed by Pellon \& Sinskey, 1984). Evidence supporting this idea is of three types: first, genetic loss of certain DNA-repair functions sensitizes Escherichia coli to heat (Bridges et al., 1969a,b); second, mild heat produces singleand double-strand breaks in DNA which are repaired during subsequent incubation in buffer with coincident restoration of viability (Sedgwick \& Bridges, 1972; Woodcock \& Grigg, 1972); third, mild heat induces changes in the sedimentation coefficient of the bacterial nucleoid (Pellon \& Sinskey, 1984).

Despite this evidence there remains uncertainty about the role of DNA damage in thermal inactivation and the mechanism by which strand breaks occur. Sedgwick \& Bridges (1972) reported that the kinetics of strand breakage and their relation to loss of viability varied depending on the strain tested. They proposed that the mechanism of DNA strand breakage was indirect, possibly involving the action of a nuclease. Williams-Hill \& Grecz (1983) subsequently showed that strains lacking an apurinic endonuclease were more resistant to mild heat and sustained fewer strand breaks in their DNA than the corresponding parent organisms.

The recovery of several species of bacteria following heat injury is improved by incorporating catalase in recovery media, implying that heated cells are sensitive to hydrogen peroxide (BairdParker \& Davenport, 1965; Brewer et al., 1977; Rayman et al., 1978; Mackey \& Derrick, 1982). Hydrogen peroxide causes several types of damage to DNA, therefore peroxide, or oxygencontaining radicals derived from it, could constitute an indirect mechanism of DNA damage in heated cells.

In this paper we examine the effects of catalase and hydrogen peroxide on the viability of DNA-repair mutants of $E$. coli injured by mild heating. 
Table 1. Strains used and their source

\begin{tabular}{|c|c|c|c|}
\hline Strain & Relevant genotype & Reference & Source* \\
\hline $\begin{array}{l}\text { AB1157 } \\
\text { AB1886 } \\
\text { AB1885 } \\
\text { AB2463 } \\
\text { AB2470 } \\
\text { AB2494 } \\
\text { AB2474 } \\
\text { AB2480 } \\
\text { JC9239 }\end{array}$ & $\begin{array}{l}\text { Parent } \\
\text { uvrA6 } \\
\text { uvrB5 } \\
\operatorname{rec} A 13 \text { (def) } \\
\operatorname{recB21} \\
\text { lexAl(ind) } \\
\text { lexA1 uvrA6 } \\
\operatorname{rec} A 13 \text { uvrA6 } \\
\text { recF143 }\end{array}$ & $\begin{array}{l}\text { Howard-Flanders et al. (1966) } \\
\text { Howard-Flanders \& Theriot (1966) } \\
\text { Howard-Flanders (1968) } \\
\text { Howard-Flanders et al. (1969) } \\
\text { Horii \& Clark (1973) }\end{array}$ & $\begin{array}{l}\text { CGSC } \\
\text { CGSC } \\
\text { CGSC } \\
\text { CGSC } \\
\text { B. Wilkins } \\
\text { CGSC } \\
\text { CGSC } \\
\text { CGSC } \\
\text { A. J. Clark }\end{array}$ \\
\hline $\begin{array}{l}\text { W3110 } \\
\text { p3478 }\end{array}$ & $\begin{array}{l}\text { Parent, thy } A 36 \\
\text { polAl thy } A 36\end{array}$ & De Lucia \& Cairns (1969) & $\begin{array}{l}\text { M. H. L. Green } \\
\text { M. H. L. Green }\end{array}$ \\
\hline $\begin{array}{l}\text { KL16 } \\
\text { BW9101 }\end{array}$ & $\begin{array}{l}\text { Parent } \\
\Delta(p n c A-x t h A)\end{array}$ & White et al. (1976) & $\begin{array}{l}\text { B. Weiss } \\
\text { B. Weiss }\end{array}$ \\
\hline $\begin{array}{l}\text { CSH } 7 \\
\text { UMI }\end{array}$ & $\begin{array}{l}\text { Parent } \\
\text { katEI katG14 }\end{array}$ & Loewen (1984); Loewen et al. (1985) & $\begin{array}{l}\text { S. Moss } \\
\text { S. Moss }\end{array}$ \\
\hline
\end{tabular}

- CGSC strains were received from B. Bachmann, E. coli Genetic Stock Center, Yale University, New Haven, Conn., USA. Other addresses are : B. Wilkins, Department of Genetics, University of Leicester, Adrian Building, University Road, Leicester LE1 7RH, UK; A. J. Clark, Department of Molecular Biology, University of California, Berkeley, Calif. 94720, USA; M. H. L. Green, MRC Cell Mutation Unit, University of Sussex, Falmer, Brighton BN1 9RR, UK; B. Weiss, Department of Molecular Biology and Genetics, The Johns Hopkins University School of Medicine, Baltimore, Md 21205, USA; S. Moss, School of Pharmacy and Pharmacology, University of Bath, Claverton Down, Bath BA2 7HY, UK.

\section{METHODS}

Bacteria. Strains of E. coli $\mathrm{K} 12$ used in this work are listed in Table 1. The complete genotypes are described in the references listed in the table.

Media diluents and buffer. Tryptone soya broth (TSB Oxoid CM129) was supplemented with $0.3 \%(w / v)$ yeast extract and, where necessary, $20 \mu \mathrm{g}$ thymidine $\mathrm{ml}^{-1}$. The corresponding agar (TSA) contained $1 \cdot 2 \%(\mathrm{w} / \mathrm{v}) \mathrm{New}$ Zealand agar. Where indicated, catalase (Sigma C40;0.08 ml of a $2 \mathrm{mg} \mathrm{ml}^{-1}$ solution containing 1760 units) was spread over the surface of agar plates and allowed to dry. $\mathrm{M} 9$ minimal medium contained, per litre: $\mathrm{Na}_{2} \mathrm{HPO}_{4}$, $6 \mathrm{~g} ; \mathrm{KH}_{2} \mathrm{PO}_{4}, 3 \mathrm{~g} ; \mathrm{NaCl}, 0.5 \mathrm{~g} ; \mathrm{NH}_{4} \mathrm{Cl}, 1 \mathrm{~g} ; \mathrm{CaCl}_{2}, 0.011 \mathrm{~g} ; \mathrm{MgSO}_{4} .7 \mathrm{H}_{2} \mathrm{O}, 0.246 \mathrm{~g} ;$ glucose, $2 \mathrm{~g}$. Amino acids to satisfy auxotrophic requirement were added at $20 \mu \mathrm{g} \mathrm{ml} \mathrm{l}^{-1}$. Peptone saline contained per litre: Bacto peptone (Difco $\mathrm{B} 118$ ), $1 \mathrm{~g} ; \mathrm{NaCl}, 8.5 \mathrm{~g}$; adjusted to $\mathrm{pH} \mathrm{7.0.} \mathrm{The} \mathrm{phosphate} \mathrm{buffer} \mathrm{used} \mathrm{in} \mathrm{these} \mathrm{experiments} \mathrm{was} 0.1 \mathrm{M}$ potassium phosphate $\mathrm{pH} 6.0$ unless otherwise stated.

Growth of organisms and heat treatment. Cells were grown for $16-20 \mathrm{~h}$ at $37^{\circ} \mathrm{C}$ in $10 \mathrm{ml} \mathrm{TSB}$ contained in a $50 \mathrm{ml}$ conical flask in a water bath set at 100 r.p.m. Stationary phase culture $(0.2 \mathrm{ml})$ was inoculated into $50 \mathrm{ml}$ fresh medium in a $250 \mathrm{ml}$ flask shaken at 300 r.p.m. When the $O_{680}$ had reached 0.5 , cells $(11 \mathrm{ml})$ were harvested by filtration washed once and resuspended in $7 \mathrm{ml}$ phosphate buffer. Washed cell suspension $(0.3 \mathrm{ml})$ was placed in a freeze-drying ampoule $(100 \times 7 \mathrm{~mm})$ which was then sealed in a gas flame. Sealed ampoules were immersed in a water bath at $52^{\circ} \mathrm{C}$ for predetermined intervals, then removed and placed in ice.

Viable counts. Serial decimal dilutions were made in peptone saline and duplicate or quadruplicate $0.02 \mathrm{ml}$ volumes, delivered from $20 \mathrm{SWG}$ stainless steel cannulae, were spread on quarter sections of agar plates. Colonies were counted after $24 \mathrm{~h}$ incubation at $37^{\circ} \mathrm{C}$. Despite careful standardization of growth, harvesting and heating conditions, variations in survival curves were observed between replicate experiments, especially when these were done many months apart. The reason for this is not known but it may have been due to slight variations between different batches of diluent, media, etc. To take account of this variation, heat survival curves of mutants were compared with the wild-type strain tested on the same day and using the same batch of media and diluents.

The degree of variation was calculated for data shown in Fig. 1 in which each plotted point is the mean value from three independent experiments. Standard errors of the mean count increased with heating time and were greater on TSA than on TSA plus catalase. The range of standard errors were $0-0.43$ and $0-0.53 \log _{10}$ units for counts on TSA and TSA plus catalase respectively. Survival curves shown in other figures are from single, representative experiments.

Peroxide sensitivity. E. coli $\mathrm{p} 3478$ was grown to $\mathrm{OD}_{680} 0 \cdot 5$, harvested by filtration, then resuspended in twice the original volume of phosphate buffer. Portions $(0.1 \mathrm{ml})$ of suspension were added to $9.9 \mathrm{ml} \mathrm{M} 9$ medium plus thymidine, with or without $25 \mu \mathrm{M}-\mathrm{H}_{2} \mathrm{O}_{2}$, incubated at $37^{\circ} \mathrm{C}$. Samples $(1 \mathrm{ml})$ were withdrawn at intervals and added to $9 \mathrm{ml}$ peptone saline containing 1760 units catalase. Cells heated at $52^{\circ} \mathrm{C}$ for 6 min in sealed ampoules were treated similarly. Viable counts were determined after appropriate dilution. 
Enzymes. Catalase activity was measured by the method of Rorth \& Jensen (1967) using a Clark oxygen electrode (Yellow Springs Instruments). Cells were grown to $\mathrm{OD}_{680} 0 \cdot 5$, harvested by centrifugation, then washed and resuspended in phosphate buffer to $\mathrm{OD}_{680} 10.0 ; 1 \mathrm{ml}$ of this concentrated suspension was added to $9 \mathrm{ml}$ buffer pre-heated to $54.5^{\circ} \mathrm{C}$. This raised the temperature of the suspension to $52^{\circ} \mathrm{C}$ instantaneously. The tube containing the suspension was quickly transferred to a water bath at $52^{\circ} \mathrm{C}$ and samples $(1 \mathrm{ml})$ were removed at intervals thereafter for catalase determination. The reaction mixture contained $1 \mathrm{ml}$ cell suspension, $2 \mathrm{ml}$ phosphate buffer and $15 \mathrm{~mm}-\mathrm{H}_{2} \mathrm{O}_{2}$. Protein was measured by the method of Lowry. Catalase C-40, peroxidase P-8250 and superoxide dismutase S-8254, used in the protection experiment, were from Sigma.

DNA degradation. Cells were labelled by inoculating $0.04 \mathrm{ml}$ of an $18-24 \mathrm{~h}$ culture in TSB plus $2 \mu \mathrm{g}$ thymidine

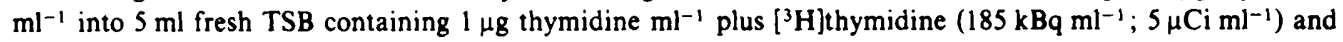
incubating until the $\mathrm{OD}_{680}$ was about 0.5 . Cells were harvested by filtration, washed with 6 vols phosphate buffer, then resuspended in $5 \mathrm{ml}$ buffer. Samples $(1 \mathrm{ml})$ were heated by adding to a test tube immersed in a water bath at $52{ }^{\circ} \mathrm{C}$. After $6 \mathrm{~min}$ the tube was placed in ice and $0.2 \mathrm{ml}$ volumes were added to $10 \mathrm{ml} \mathrm{TSB}$ or M9 plus thymidine $\left(3 \mu \mathrm{g} \mathrm{m}^{-1}\right)$ with and without catalase $(1760$ units per tube). Portions $(0.15 \mathrm{ml})$ of suspension were removed at intervals and spotted onto filter paper (Whatman $3 \mathrm{M}$ ). When dry the filter papers were washed twice in $5 \%(w / v)$ ice-cold trichloroacetic acid, and once each in $95 \%$ ethanol and acetone. The dry filters were counted in Instagel scintillation fluid (Packard Instrument Co.).

\section{RESULTS}

Effect of catalase on viable counts

Survival curves of strains of $E$. coli heated in phosphate buffer at $52{ }^{\circ} \mathrm{C}$ are shown in Figs 1 and 2. Data are normalized so that the initial (unheated) counts on TSA plus catalase equal $100 \%$ for all strains. When viability was compared with the wild-type on TSA, the recA13 and polAI strains were apparently more heat sensitive whereas the uvrA6 strain was of equal heat resistance (Fig. $1 a$ ). However, when catalase was present in the plating medium there were no significant differences between strains (Fig. 1b).

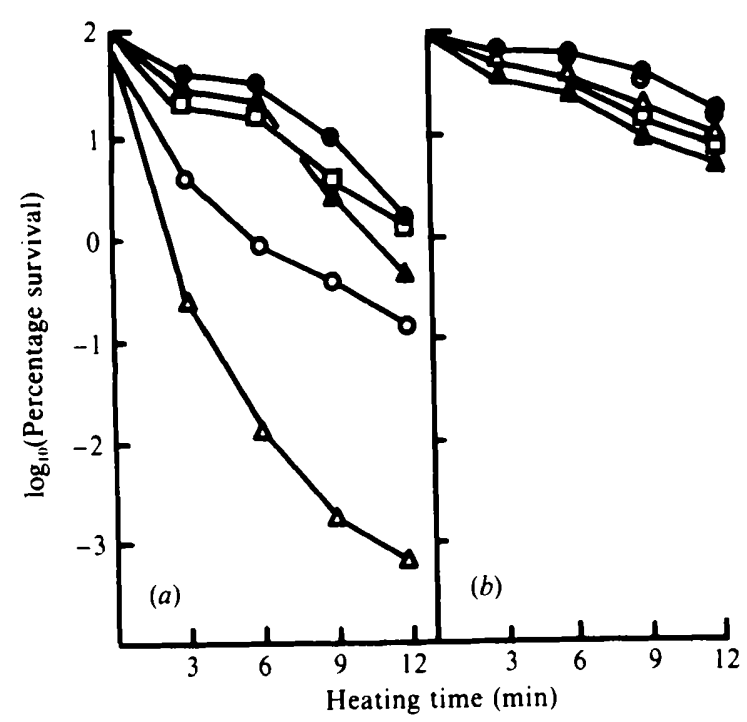

Fig. 1

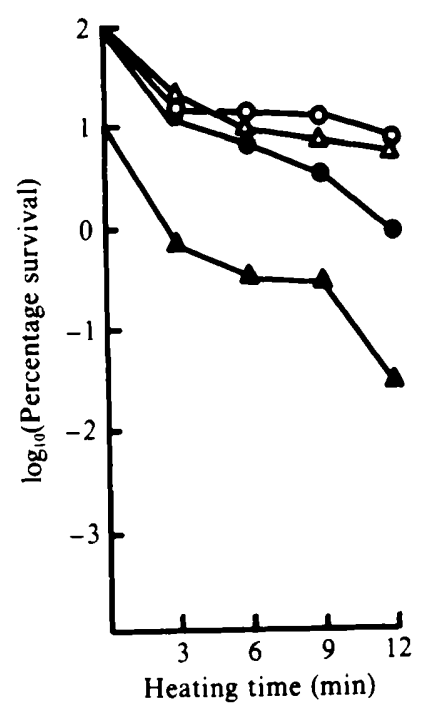

Fig. 2

Fig. 1. Survival of bacteria heated at $52^{\circ} \mathrm{C}$. Viable counts estimated on TSA $(a)$ or TSA plus catalase $(b)$. , Wild-type AB1157; $\triangle$, wild-type W3110; $\mathrm{O}, \mathrm{AB} 2463 \mathrm{rec} A 13 ; \triangle$, W3110 polAI; $\square, \mathrm{AB} 1886$ uvr $A 6$.

Fig. 2. Survival of bacteria heated at $52^{\circ} \mathrm{C}$. Viable counts estimated on TSA $(O, \triangle)$ or TSA plus catalase $(O, \triangle)$.,$O$, Wild-type AB1157; $\triangle, \triangle \mathrm{AB} 2474$ uvrA6 lexA1. 


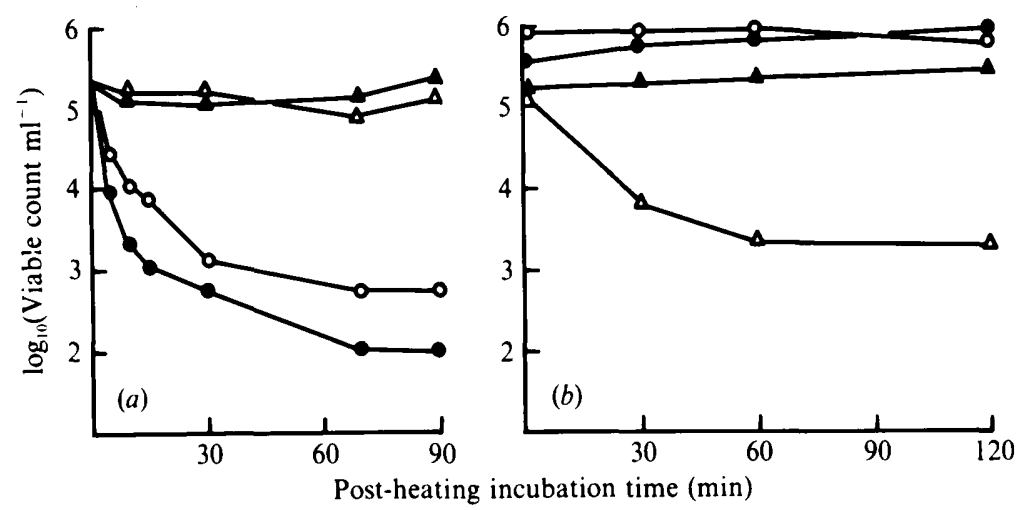

Fig. 3. Loss of viability of heat-injured $E$. coli p3478 polAl exposed to rich medium or hydrogen peroxide. (a) Bacteria heated at $52^{\circ} \mathrm{C}$ for $6 \mathrm{~min}$ were inoculated into TSB at $37^{\circ} \mathrm{C}$ containing: no addition $(\bigcirc)$, superoxide dismutase $(\bigcirc)$, catalase $(\triangle)$, or peroxidase $(\triangle),\left(100 \mu \mathrm{g} \mathrm{ml}^{-1}\right.$ each). (b) cells heated at $52^{\circ} \mathrm{C}$ for $6 \mathrm{~min}(\triangle, \triangle)$ or unheated $(\boldsymbol{O}, \mathrm{O})$ were inoculated into $\mathrm{M} 9$ medium at $37^{\circ} \mathrm{C}(\boldsymbol{O}, \Delta)$ or $\mathrm{M} 9$ plus $25 \mu \mathrm{M}$ hydrogen peroxide $(O, \triangle)$.

Mutations at $u v r B 5$ or $\operatorname{recF} 143$ had little effect on survival whereas $\operatorname{rec} B 2 I$ was similar in its effect to recA13 (data not shown). The effect of lexAl was more complex; on its own, lexAl had no effect on survival whereas the lexAl uvrA6 double mutant exhibited lower survival than the parent on TSA even in the initial unheated sample (Fig. 2). Similar survival curves were obtained with the uvrA6 recA13 strain and, occasionally, with the recB2l strain and an additional recA1 strain (JC 1553). In all cases, however, counts were restored to wild-type levels by the addition of catalase to recovery media. Anaerobic incubation of TSA plates without catalase did not increase recoveries significantly.

Effect of catalase, peroxidase and superoxide dismutase on post-heating survival. The results described above imply that loss of viability of heat-injured cells occurred after heating, when cells were exposed to nutritionally rich growth medium. The kinetics of viability loss on rich medium were investigated in $E$. coli $\mathrm{p} 3478$, the most sensitive strain. Heat-injured cells suspended in TSB lost viability within $30 \mathrm{~min}$ (Fig. $3 a$ ). Catalase and peroxidase were protective but superoxide dismutase had only a marginal or (in some experiments) nil effect.

Sensitivity of heat-injured cells to peroxide. Protection against loss of viability by catalase implies $(a)$ that heated cells are sensitive to peroxide and $(b)$ that peroxide is present in rich growth medium. The concentration of peroxide in 10 samples of autoclaved TSB ranged from 12 to $30 \mu \mathrm{M}$ with a mean of $20 \mu \mathrm{M}$. No peroxide was detected in M9 medium (Mackey \& Derrick, 1986). Loss of viability of heat-injured $E$. coli p3478 in M9 plus $25 \mu \mathrm{M}$-hydrogen peroxide followed a similar course to that in TSB (Fig. $3 b$ ). Unheated cells remained viable under ths same conditions.

Effect of heat on cellular catalase activity. Whole-cell catalase activity was about $85 \%$ of the level in cell extracts. Fig. 4(a) shows that whole-cell catalase activity in E. coli p3478 increased slightly during the first 3 min of heating, then declined over the next $27 \mathrm{~min}$ to $35 \%$ of the initial level. For comparison, the rate of increase in peroxide sensitivity (as indicated by the difference in viable count on TSA and TSA plus catalase) is shown on the same diagram (data taken from Fig $1 a$ ). Peroxide sensitivity evidently occurs before any substantial loss of total catalase activity.

E. coli contains two catalases (hydroperoxidases), designated HPI and HPII (Claiborne \& Fridovich, 1979; Claiborne et al., 1979; Loewen, 1984; Loewen et al., 1985; Meir \& Yagil, 1984, 1985). The HPI enzyme possesses catalase and peroxidase activity, is inducible and heat labile whereas HPII lacks peroxidase activity, is constitutive and relatively heat stable. To examine the effect of heat on cellular HPI activity, the experiment described above, using E. coli p3478, 

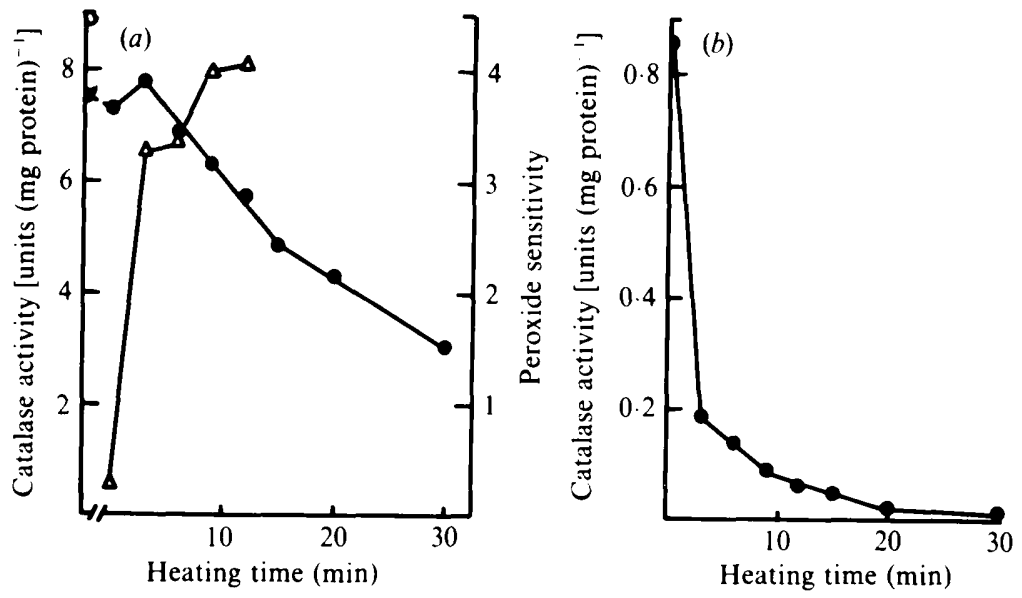

Fig. 4. Inactivation of catalase during heating of $E$. coli at $52^{\circ} \mathrm{C}$. (a) , Whole-cell catalase activity of $E$. coli p347.8 pol $\mathrm{Al} ; \mathrm{O}$, catalase activity of cell extract of unheated cells; $\triangle$, increase in peroxidesensitivity measured as the difference in $\log _{10}$ count on TSA and on TSA plus catalase (data recalculated from Fig. 1). (b) Inactivation of HPI during heating of $E$. coli UMI at $52{ }^{\circ} \mathrm{C}$.

was repeated using E. coli UM1, which lacks HPII. Cells were grown in LB medium, which contains no glucose, rather than TSB, to ensure that HPI was present at reasonably high levels. In contrast to total catalase activity, HPI activity declined rapidly during heating at $52{ }^{\circ} \mathrm{C}$, decreasing to $22 \%$ of its initial level within $3 \mathrm{~min}$ (Fig. $4 \mathrm{~b}$ ). Inactivation of total catalase in the parent strain CSH7, also grown in LB medium, followed a similar course to that of strain p3478 grown in TSB, although absolute activities were slightly higher throughout (data not shown). Heat-injured cells of strain UMI were no more sensitive to peroxide in plating media than cells of the parent strain $\mathrm{CSH} 7$ (data not shown).

Effect of the xthA mutation on heat resistance. Lack of exonuclease III did not affect heatinduced peroxide sensitivity as judged by the difference between counts on TSA and TSA plus catalase for the two strains. However, strain BW9101 was slightly more heat resistant than KL16 irrespective of the recovery medium used to assess viability. After 12 min heating at $52{ }^{\circ} \mathrm{C}$, percentage survival was 4.3 and 0.57 for strains BW 9101 and KL16 respectively with TSA plus catalase as recovery medium, and 0.54 and $0.35 \%$ with TSA minus catalase.

DNA breakdown in E. coli p3478. Heat-injured cells of E. coli $\mathrm{p} 3478$ degraded about $26-28 \%$ of their DNA over $2 \mathrm{~h}$ when incubated in TSB or M9 medium. Addition of catalase to the media reduced this to $9-10 \%$. Similar degradation (about $20 \%$ ) also occurred when cells were washed in phosphate buffer but not heated before adding to TSB. The extent of this degradation in unheated cells was reduced to about $12 \%$ if the washing buffer contained $10 \mathrm{mM}-\mathrm{MgCl}_{2}$ (data not shown).

Repair of heat injury. When heat-injured cells of $E$. coli p3478 were incubated in M9 medium, colony counts on TSA increased to equal those on TSA plus catalase, i.e. cells recovered the ability to grow on peroxide-containing medium (Fig. $5 a$ ). By contrast, colony counts on TSA plus catalase decreased to the level on TSA when cells were incubated in TSB, i.e. peroxidesensitive cells died. Similar results were obtained with AB2463 recA13 (data not shown). The wild-type AB1157 repaired injury in M9 or TSB, although repair took longer in TSB (Fig. $5 b$ ). (Note that AB1 157 was heated for $12 \mathrm{~min}$ rather than $6 \mathrm{~min}$ to obtain a sufficient difference between counts on the two media for repair to be measurable.) The decline in viability in M9 subsequent to repair was somewhat variable and was not investigated further. Strain AB2494 lexAl repaired in $\mathrm{M} 9$ but showed simultaneous repair and loss of viability in TSB (data not shown). Repair in M9 thus occurred in wild-type, lexA1, rec 113 and polAl strains, but only the wild-type and the lexAl strain (partially) could repair in TSB. 


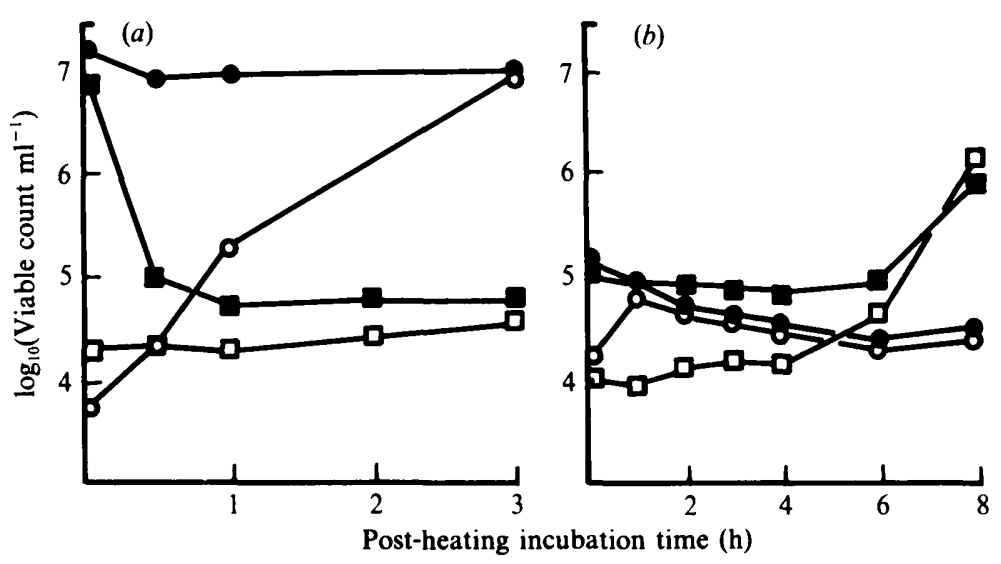

Fig. 5. Repair of heat injury in (a) E. coli 3478 polA and $(b) E$. coli AB1 157 wild-type. Cells were heated in phosphate buffer at $52^{\circ} \mathrm{C}$ for $(a) 6 \mathrm{~min}$ or $(b) 12 \mathrm{~min}$, then inoculated into M9 $(O, O)$ or TSB $(\square, \square)$. Viable counts were determined at intervals on TSA $(O, \square)$ or TSA plus catalase $(O, \square)$.

\section{DISCUSSION}

In agreement with previous workers we have found that mutants of $E$. coli lacking certain DNA-repair functions are more sensitive to mild heat than wild-type strains (Bridges et al., 1969a,b; Pauling \& Beck, 1975; Ahmad et al., 1978). However, this thermosensitivity is only apparent, and results from a heat-induced sensitivity to the low levels of peroxide present in rich media used to assess viability. Heat-injured DNA-repair mutants are more peroxide-sensitive than repair-competent strains and therefore form fewer colonies when plated on rich medium.

Mutations having the greatest effect on apparent heat sensitivity were, in order of increasing effect : lex $A 1$, recA13 or recB2l and polAI. Strains carrying uvr $A 6$, uvrB5 or recF 143 mutations were of similar resistance to the wild-type. The effect of DNA-repair mutations on heat resistance has been examined previously by others (Bridges et al., 1969 a, $b$; Sedgwick \& Bridges, 1972; Ahmad et al., 1978). There is agreement that the recA13 mutation sensitizes cells to heat whereas $u v r A$ or $u v r B$ mutations are without effect. There are differences in the reported effects of other mutations. Both we and Ahmad et al. (1978) found E. coli $\mathrm{p} 3478$ pol Al to be much more heat sensitive than the parent W3110 whereas Sedgwick \& Bridges (1972) found no difference between these two strains but did find $E$. coli R 15 res to be more heat sensitive than the parent $\mathrm{H} / \mathrm{r} 30-\mathrm{R}$ (the res allele in $E$. coli B strains is analogous to polA in $\mathrm{K} 12$ strains). The effect of the lexAl mutation on apparent heat resistance is difficult to interpret; on its own, lexAl had little effect, but the lexAl uvrA6 strain was sensitive to rich medium even without prior heating and that sensitivity was not much increased by subsequent heating. This effect was sometimes observed with $\mathrm{AB} 2480 \mathrm{uvr} A 6 \mathrm{rec} A 13$, JC1553 recAl and, more rarely, $\mathrm{AB} 2470 \mathrm{recB} 21$. Cold shock or diluent stress can induce sensitivity to peroxide (Mackey \& Derrick, 1986) and we suspect that the strains described above are particularly sensitive to the washing procedures used in preparing cell suspensions.

If LB agar, which contains less peroxide, was substituted for TSA, the initial (unheated) counts of strain AB2474 lexAl uvrA6 on media with and without catalase were similar, but sensitivity to LB agar (minus catalase) developed during heating (data not shown), i.e. when LB agar was used as recovery medium AB2474 lexAl uvrA6 displayed apparent heat sensitivity. Our results are thus somewhat similar to those of Bridges et al. (1969a) who found that lexA (ind) had little effect on heat resistance unless combined with uvr or lon mutations. In contrast, Ahmad et al. (1978) found the lex $A 1$ strain to be as heat sensitive as the rec $A 13$ strain and further differed from us in finding no effect of $r e c B 21$.

The reason for the discrepant results with polAl and other strains is not clear at present but may be related to different levels of peroxide in media used to assess viability and also to differences in diluents used for washing and heating cells which may affect membrane integrity (see below). 
Survival curves of heated cells were often triphasic, containing initial and final steep portions and a central plateau (e.g. see strains AB1157, AB1886 and W3110 in Fig. 1a). This was reproducible and has been reported previously by Grecz et al. (1985), who ascribed the effect to heat-shock-induced thermotolerance. We have not investigated the phenomenon further. The non-linear kinetics preclude resistances being compared on the basis of the gradients of the slopes of the survival curves.

If the apparent heat sensitivity of DNA-repair mutants is due to their greater sensitivity to peroxide in recovery media, one would expect there to be a correlation between sensitivity to heat and to authentic peroxide. The peroxide sensitivity of the relevant DNA-repair-deficient strains has been examined by several workers (Carlsson \& Carpenter, 1980; Ananthaswamy \& Eisenstark, 1977; Imlay \& Linn, 1986). There is agreement that the $\operatorname{rec} A(\operatorname{def})$ mutation sensitizes cells to peroxide whereas $u v r A$ and $u v r B$ mutations do not. This corresponds exactly with the effect of these mutations on heat resistance. As with sensitivity to heat there are differing reports on the effect of the polA mutation on peroxide sensitivity. Ananthaswamy \& Eisenstark (1977) and Imlay \& Linn (1986) found that polA strains were more sensitive than wild-type strains to $10 \mathrm{mM}$ - and up to $3 \mathrm{mM}-\mathrm{H}_{2} \mathrm{O}_{2}$ respectively, whereas Carlsson \& Carpenter (1980) found no increased sensitivity of a polA strain to $0.2 \mathrm{~mm}-\mathrm{H}_{2} \mathrm{O}_{2}$. Our results and those of Imlay \& Linn (1986) showed $\operatorname{rec} B$ strains to be more peroxide sensitive than the wild-type whereas Ananthaswamy \& Eisenstark found that $\operatorname{rec} B$ had a negligible effect.

It has recently become apparent that the response of cells to challenge by hydrogen peroxide is highly dependent on the growth conditions of the cells before the challenge, the temperature and composition of any diluents used to wash the cells, and the concentration of peroxide to which the cells are exposed (Mackey \& Derrick, 1986; Imlay \& Linn, 1986). It is thus likely that differences in experimental conditions could account for discrepant results reported by different workers.

However, despite individual differences, one can conclude that DNA-repair mutations that sensitize cells to hydrogen peroxide also cause increased (apparent) sensitivity to heat (the $x$ th mutation is an exception which will be discussed below).

The mechanism by which peroxide causes cell-death is not clear at present. The simplest explanation is that, in heat-injured cells, peroxide causes damage to DNA which is inefficiently repaired in pol $A, \operatorname{rec} A$ (def), $\operatorname{rec} B$ and possibly lex $A$ (ind) strains. The $u v r A, u v r B$ and $\operatorname{rec} F$ functions are apparently less important in repairing this type of damage. The nature of the DNA damage is unknown but could be any of a variety of lesions caused by peroxide, including strand breakages, depurination and addition reactions with the double bond of bases (Yamafugi \& Uchida, 1966; Rhaese \& Freese, 1968; Demple \& Linn, 1982). Strand breaks in DNA were detected when heated cells of Salmonella typhimurium were exposed to rich medium (Gomez \& Sinskey, 1973). Our results suggest that oxidative damage could have been involved in this phenomenon.

The $x$ th $A$ gene codes for exonuclease III, a multifunctional enzyme possessing $3^{\prime} \rightarrow 5^{\prime}$ exonuclease, apurinic endonuclease, phosphatase and ribonuclease $\mathrm{H}$ activities (Weiss, 1981). Cells lacking the enzyme are hypersensitive to hydrogen peroxide (Demple et al., 1983) but the heat-injured $x$ th $A$ strain was no more sensitive than the wild-type to the low levels of peroxide in rich media. This could suggest that DNA damage caused by exposing unheated cells to reagent hydrogen peroxide differs from that caused by exposing heat-injured cells to complex media. Both types of lesion appear to require $\mathrm{pol} \mathrm{A}^{+}$and $\mathrm{rec} \mathrm{A}^{+}$functions whereas only the former requires $x \operatorname{th} A^{+}$. However, this conclusion is complicated by the fact that the normal physiological functions of exonuclease III are disturbed in heat-injured cells. Williams-Hill \& Grecz (1983) showed that $E$. coli $x$ th strains lacking exonuclease III sustained fewer DNA strand breaks during heating and survived better than otherwise isogenic $x t h A^{+}$strains. They suggested that mild heating triggered exonuclease III activity leading to DNA damage and death of the cell. In our experiments catalase improved the recovery of both $x \operatorname{th} A$ and wild-type organisms, implying that exonuclease III activity is not required for peroxide-induced loss of viability in heat-injured cells and, conversely, that exposure to peroxide in rich media is not necessary for exonuclease III-mediated cell death. 
Gross degradation of DNA occurs in polA strains of $E$. coli following DNA damage caused by ultraviolet or ionizing radiation and is believed to contribute to the radiation sensitivity of these strains (Boyle et al., 1970). When heat-injured E. coli $\mathrm{p} 3478$ polA was resuspended in TSB, loss of viability and degradation of DNA occurred, both of which were reversed by catalase. However DNA degradation seems unlikely to account for loss of viability because the kinetics of the two processes were very different and heated cells resuspended in M9 medium degraded similar amounts of DNA with no loss of viability.

The increased sensitivity of heat-injured cells to low levels of peroxide in rich media is not due to a decrease in total catalase activity but may be related specifically to the inactivation or loss of catalase HPI. E. coli UMI lacks the major constitutive catalase (HPII) and reportedly contains only the peroxidatic activity associated with the minor, inducible catalase, HPI (Loewen et al., 1985). In our hands strain UMI contained measurable residual catalase activity; because of its heat sensitivity, we believe this activity most likely to be associated with HPI (Meir \& Yagil, 1985). The decrease in HPI activity that occurred under our heating conditions was sufficiently rapid to account for the correspondingly rapid increase in peroxide sensitivity. The $K_{\mathrm{m}}$ for $\mathrm{H}_{2} \mathrm{O}_{2}$ of HPI (about $3.7 \mathrm{~mm}$ ) is much lower than that of the more thermostable HPII (reported as 18.2 or $30.9 \mathrm{mM}$ ) (Claiborne \& Fridovich, 1979; Loewen \& Triggs, 1984; Meir \& Yagil, 1985) and is consistent with a protective function against low concentrations of peroxide. Chilling exponentially growing cells of $S$. typhimurium or $E$. coli also induces sensitivity to peroxide (Mackey \& Derrick, 1986). These procedures and heating both affect membrane integrity and it is thus possible that membrane damage contributes to the enhanced sensitivity to peroxide.

When heat-injured cells were resuspended in minimal medium, colony counts on TSA increased to the level found on TSA plus catalase, i.e. cells recovered ability to grow on peroxidecontaining media. We believe, therefore, that recovery of peroxide resistance accounts for the liquid holding recovery of heat-injured cells reported by others (Hershey, 1939; Mukherjee \& Bhattacharjee, 1970; Stiles et al., 1973; Gomez et al., 1973; Ahmad et al., 1978). The recovery process was independent of $l e x A, \operatorname{rec} A$ or polA and probably reflects repair or resynthesis of structures other than DNA, possibly HPI and the cell membrane. The process therefore differs from the 'minimal medium recovery' of ultraviolet-irradiated cells, which requires a functional rec $A$ gene (Sharma et al., 1982).

Ahmad et al. (1978) found that the extent of liquid holding recovery of heated $E$. coli depended on the composition of growth and recovery media: when cells were grown in rich medium, heated then resuspended in minimal medium, no recovery took place within $2 \mathrm{~h}$ in wild-type, $\operatorname{lex} A$ (ind), $\operatorname{rec} A$ or polA strains. We cannot explain why their results $\operatorname{differ}$ from ours but differences in the severity of heat treatment could be important.

To conclude, we support the notion that DNA damage caused by mild heating can occur indirectly and propose oxidative attack to DNA as a possible mechanism additional to the previously suggested endonucleolytic attack. The reason why heated cells are sensitive to peroxide and the nature of damage to DNA remain to be clarified.

We are very grateful to Drs B. A. Bachmann, B. Wilkins, A. J. Clark, M. H. L. Green, B. Weiss and S. Moss who kindly provided strains and O. P. Whelehan and I. Bratchell for statistical assistance.

\section{REFERENCES}

Ahmad, M., Srivastava, B. S. \& Agarwala, S. C. (1978). Effect of incubation media on the recovery of Escherichia coli $\mathrm{K} 12$ heated at $52^{\circ} \mathrm{C}$. Journal of General Microbiology 107, 37-44.

ANanthaswamy, H. N. \& EisenstaRk, A. (1977). Repair of hydrogen peroxide-induced single strand breaks in Escherichia coli deoxyribonucleic acid. Journal of Bacteriology 130, 187-191.

Baird-Parker, A. C. \& DavenPort, E. (1965). The effect of recovery medium on isolation of Staphylococcus aureus after heat-treatment and after storage of frozen or dried cells. Journal of Applied Bacteriology 28, 390-402.

Boyle, J. M., Paterson, M. C. \& Setlow, R. B. (1970). Excision-repair properties of an Escherichia coli mutant deficient in DNA polymerase. Nature, London 226, 708-710.

Brewer, D. G., Martin, S. E. \& Ordal, Z. J. (1977). Beneficial effects of catalase or pyruvate in a mostprobable number technique for the detection of Staphylococcus aureus. Applied and Environmental Microbiology 34, 797-800. 
Bridges, B. A., Ashwood-Smith, M. J. \& Munson, R. J. (1969a). Correlation of bacterial sensitivities to ionizing radiation and mild heating. Journal of General Microbiology 58, 115-124.

Bridges, B. A., Ashwood-Smith, M. J. \& Munson, R. J. $(1969 b)$. Susceptibility of mild thermal and ionising radiation damage to the same recovery mechanisms in Escherichia coli. Biochemical and Biophysical Research Communications 35, 193-196.

Carlsson, J. \& Carpenter, V. S. (1980). The rec $A^{+}$ gene product is more important than catalase and superoxide dismutase in protecting Escherichia coli against hydrogen peroxide toxicity. Journal of Bacteriology 142, 319-321.

Claiborne, A. \& Fridovich, I. (1979). Purification of the $o$-dianisidine peroxidase from Escherichia coli B. Journal of Biological Chemistry 254, 4245-4252.

Claiborne, A., Malinowski, D. P. \& Fridovich, I. (1979). Purification and characterisation of hydroperoxidase II of Escherichia coli. Journal of Biological Chemistry 254, 11664-11668.

De LuCIA, P. \& CaIRns, J. (1969). Isolation of an Escherichia coli strain with a mutation affecting DNA polymerase. Nature, London 244, 1164-1166.

DEMPLE, B. \& LINN, S. (1982). 5-6-saturated thymine lesions in DNA: production by ultraviolet light or hydrogen peroxide. Nucleic Acids Research 10, 37813789.

Demple, B., Halbrook, J. \& LinN, S. (1983). Escherichia coli xth mutants are hypersensitive to hydrogen peroxide. Journal of Bacteriology 153, 1079-1082.

Gomez, R. F. \& Sinskey, A. J. (1973). Deoxyribonucleic acid breaks in heated Salmonella typhimurium LT2 after exposure to nutritionally complex media. Journal of Bacteriology 115, 522-528.

GreCZ, N., JAW, R. \& McGarRY, T. J. (1985). Genetic control of heat resistance and thermotolerance by $\operatorname{rec} A$ and uvr $A$ in Escherichia coli K12. Mutation Research 145, 113-118.

HeRSHEY, A. D. (1939). Factors limiting bacterial growth. VII. Respiration and growth properties of Escherichia coli surviving sublethal temperatures. Journal of Bacteriology 38, 563-578.

HoRII, Z. I. \& ClARK, A. J. (1973). Genetic analysis of the recF pathway of genetic recombination in Escherichia coli $\mathrm{K} 12$ : isolation and characterisation of mutants. Journal of Molecular Biology 80, 327-344.

Howard-Flanders, P. (1968). Genes that control DNA repair and genetic recombination in Escherichia coli. Advances in Biological and Medical Physics 12, 299-317.

Howard-Flanders, P. \& Theriot, L. (1966). Mutants of Escherichia coli $\mathrm{K} 12$ defective in DNA repair and in genetic recombination. Genetics 53, 1137-1150.

Howard-Flanders, P., Boyce, R. P. \& Theriot, L. (1966). Three loci in Escherichia coli $\mathrm{K} 12$ that control the excision of pyrimidine dimers and certain other mutagen products from DNA. Genetics 53, 1119 1136.

Howard-Flanders, P., Theriot, L. \& Stedeford, J. B. (1969). Some properties of excision-defective recombination-deficient mutants of Escherichia coli K12. Journal of Bacteriology 97, 1134-1141.

HURST, A. (1984). Revival of vegetative bacteria after sublethal heating. In The Revival of Injured Microbes
(Society for Applied Bacteriology Symposium Series no. 12), pp. 77-103. Edited by M. H. E. Andrew \& A. D. Russell. London: Academic Press.

IMLAY, J. A. \& LINN, S. (1986). Bimodal pattern of killing of DNA-repair-defective or anoxically grown Escherichia coli by hydrogen peroxide. Journal of Bacteriology 166, 519-527.

LOEWEN, P. C. (1984). Isolation of a catalase-deficient Escherichia coli mutant and genetic mapping of kat E, a locus that affects catalase activity. Journal of Bacteriology 157, 622-626.

Loewen, P. C. \& Triggs, B. L. (1984). Genetic mapping of $k a t F$, a locus that with kat $E$ affects the synthesis of a second catalase species in Escherichia coli. Journal of Bacteriology 160, 668-675.

Loewen, P. C., Triggs, B. L., George, C. S. \& HrabarchuK, B. E. (1985). Genetic mapping of $k a t G$, a locus that affects synthesis of the bifunctional catalase-peroxidase hydroperoxidase $I$ in Escherichia coli. Journal of Bacteriology 162, 661667.

MaCkeY, B. M. \& Derrick, C. M. (1982). A comparison of solid and liquid media for measuring the sensitivity of heat-injured Salmonella typhimurium to selenite and tetrathionate media and the time needed to recover resistance. Journal of Applied Bacteriology 53, 233-242.

MACKeY, B. M. \& Derrick, C. M. (1986). Peroxide sensitivity of cold-shocked Salmonella typhimurium and Escherichia coli and its relationship to minimal medium recovery. Journal of Applied Bacteriology 60 , 501-511

MeIR, E. \& YAGIL, E. (1984). Catalase negative mutants of Escherichia coli. Current Microbiology 11 , 13-18.

MEIR, E. \& YAGIL, E. (1985). Further characterisation of the two catalases in Escherichia coli. Current Microbiology 12, 315-320.

MukherJeE, P. \& Bhattacharjee, S. B. (1970). Recovery of bacteria from damages induced by heat. Journal of General Microbiology 60, 233-238.

Pauling, C. \& Beck, L. A. (1975). Role of DNA ligase in the repair of single strand breaks induced in DNA by mild heating of Escherichia coli. Journal of General Microbiology 87, 181-184.

Pellon, J. R. \& Sinskey, A. J. (1984). Heat-induced damage to the bacterial chromosome and its repair. In The Revival of Injured Microbes (Society for Applied Bacteriology Symposium Series no. 12), pp. 105-125. Edited by M. H. E. Andrew \& A. D. Russell. London: Academic Press.

Rayman, M. K., Aris, B. \& El Derea, H. B. (1978). The effect of compounds which degrade hydrogen peroxide on the enumeration of heat-stressed cells of Salmonella senftenberg. Canadian Journal of Microbiology 24, 883-885.

Rhaese, H. J. \& Freese, E. (1968). Chemical analysis of DNA alterations. I. Base liberation and backbone breakage of DNA and oligodeoxyadenylic acid induced by hydrogen peroxide and hydroxylamine. Biochimica et biophysica acta 155, 476-490.

RORTH, M. \& JENSEN, P. K. (1967). Determination of catalase activity by means of the Clark oxygen electrode. Biochimica et biophysica acta 139, 171-173.

Sedgwick, S. G. \& BRIDGeS, B. A. (1972). Evidence for indirect production of DNA strand scissions 
during mild heating of Escherichia coli. Journal of General Microbiology 71, 191-193.

SHARMA, R. C., BARFKNECHT, T. R. \& SMITH, K. C (1982). Postreplication repair in $u v r A$ and $u v r B$ strains of Escherichia coli $\mathrm{K} 12$ is inhibited by rich growth medium. Photochemistry and Photobiology 36, 307-311.

Stiles, M. E., Roth, L. A. \& ClegG, L. F. L. (1973). Heat injury and resuscitation of Escherichia coli. Canadian Institute of Food Science and Technology 6, 226-229.

WEISS, B. (1981). Exodeoxyribonucleases of Escherichia coli. In The Enzymes, vol. 14, pp. 203-231. Edited by P. D. Boyer. New York: Academic Press.
White, B. J., Hochrauser, S. J., Cintron, N. M. \& WEISS, B. (1976). Genetic mapping of $x t h A$, the structural gene for exonuclease III in Escherichia coli K12. Journal of Bacteriology 126, 1082-1088.

Williams-Hill, D. M. \& GreCZ, N. (1983). Role of AP endonuclease in DNA breakage and cell inactivation of Escherichia coli subjected to mild heat $\left(52^{\circ} \mathrm{C}\right)$. Mutation Research 107, 13-21.

Woodcock, E. \& GRIGG, G. W. (1972). Repair of thermally induced DNA breakage in Escherichia coli. Nature New Biology 237, 76-79.

YAMAFUGI, K. \& UCHIDA, Y. (1966). Liberation of adenine from deoxyribonucleic acid by hydrogen peroxide. Nature, London 209, 301-302. 